\title{
Three dimensional models of PYRGo depressa (D’ORBIGny, 1826) (FORAMINIFERA) PERFORMED WITH MICROTOMOGRAPHY TECHNIQUES
}

\section{Ulisses dardon ${ }^{1}$, Thais de Castro Cunha Parméra ${ }^{2}$, Maria Antonieta da Conceição Rodrigues ${ }^{3}$ AND MARIA Virgínia Alves MARTins ${ }^{3,4}$}

1 Programa de Pós-Graduação em Análises de Bacias e Faixas Móveis. Faculdade de Geologia, Universidade do Estado do Rio de Janeiro, Av. São Francisco Xavier, 524, sala 4037F, Maracanã, Rio de Janeiro, RJ, Brazil, CEP. 20550-013. dardonnn@gmail.com

2 Programa de Pós-graduação em Ecologia e Evolução, Universidade do Estado do Rio de Janeiro (UERJ), Av. São Francisco Xavier, 524,

PHLC $2^{\circ}$ andar, sala 224, Maracanã, 20550-013, Rio de Janeiro, RJ, Brazil. thaisparmera@yahoo.com.br

3 Universidade do Estado do Rio de Janeiro - UERJ, Faculdade de Geologia, Departamento de Estratigrafia e Paleontologia, Av. São Francisco Xavier, 524, Maracanã, sala 2020, 20550-013 Rio de Janeiro, RJ, Brazil. tutucauerj@gmail.com, virginia.martins@ua.pt.

4 Universidade de Aveiro, Departamento de Geociências, GeoBioTec, 3810-193 Aveiro, Portugal.

*Corresponding Author, virginia.martins@ua.pt

Received on 07 Fabruary 2016

Received in revised form on 09 May 2016

Accepted on 14 May 2016

Editor:

Fabrizio Frontalini, Università degli Studi di Urbino "Carlo Bo", Italy. fabrizio.frontalini@uniurb.it

\section{Abstract}

Graphic Computer and the three dimensional technique (3D) has its applicability in various fields of science, such as: medicine, zoology, botany and paleontology. In the paleontology field it has been applied, mainly in the study of vertebrates and invertebrates fossils.

The 3D-models of the scanned fossils by computed microtomography (micro-CT) allow to observe full details of its internal and external morphology. The three-dimensional model of the species provides great detailing of internal and external structures, which can contribute to a better understanding and characterization of morphological features of the analyzed materials. This work aims to detail the morphology of Pyrgo depressa (d'Orbigny, 1826) (benthic foraminifera) using the micro-CT technics.
Citation:

Dardon, U., Parméra, T.C.C., Rodrigues, M.A.C., Martins, M.V.A., 2016. Three dimensional models of Pyrgo depressa (d’Orbigny, 1826) (foraminifera) performed with microtomography techniques. Journal of Sedimentary Environments, 1(2): 216-227.

Results of imagens and of the 3D-modells obtained by micro-CT analysis allowed the observation of the initial and later chambers arrangement, the proloculus with a columnar structure and two apertures, the sequence and linearization of the apertures and toothplates of the following chambers, the walls thickness and density. The 3D-models also allow to deduce the function of teeth which is related to the initial formation of the peripheral keel.

Keywords: Pyrgo depressa. Benthic foraminifera. Morphological analysis. Computer Microtomography. 3Dtechnique 


\section{Introduction}

Several techniques are commonly used in morphological analysis such as: microscopy and scanning electron microscopy (Birkmann and Lundin, 1996, Duarte et al., 2003). The confocal microscopy and computational methods, such as Computer Tomography (CT), a threedimensional technique (3D), have been recently developed and can provide additional information (e.g. Luo and Ketten, 1991; Rowe et al., 1999; Brochu, 2000; Maisey, 2001; Dardon et al., 2010).

The 3D-technique allows to conduct highly detailed morphological analysis of fossils and living organisms. It might also assist in the identification of new species, since provides details of posture, anatomy, particularities of the endoskeleton. It can be applied in the preparation of replicas of fossils and histological models, in the study of ichnofossils and fossils biomechanics, reconstruction and articulation of the skeleton among others (Azevedo et al., 2010; Dardon et al., 2010).

This method has been applied in paleontology since the 1980s, with great success in terms of results (Azevedo and Carvalho, 2009, Mallison et al., 2009, Dardon et al., 2010).

One of the pioneering research using the 3D-technique on the analysis of mammals materials allowed the reconstruction of the structure of the inner ear (Luo and Ketten, 1991; Dardon et al., 2010).

Rowe et al. (1999), Brochu (2000) and Maisey (2001) used this technique for the three-dimensional visualization of vascular cavities and nerve structures as well as the skull of a crocodile, a dinosaur and a fish.

Most part of the works aiming to study morphological features mainly analyzes external morphological structures (i.e., Schmidt, 1952; Hay and Sandberg, 1967). Studies aiming to characterize internal details of fossils or recent organism's structures are much rarer.

Some works used this methodology to study foraminifera such as: Görög et al. (2010); Briguglio and Benedetti (2012); Briguglio et al. (2013, 2014); Ferrández-Canadell et al. (2014); Eder et al. (2016).

This study aims to apply the Computer Microtomography (Micro-CT) technique to analyze external and internal structures of a benthic foraminifera (Pyrgo depressa) species and to contribute for a better description of this species.

\subsection{Three dimensional technique for Micro-CT}

The 3D-technique for Micro-CT can produce multiple tomographic images (slices). These multiple tomographic images can be applied to a specific program for generating 3D-models which provides details of internal and external structures (Baumgartner-Mora et al., 2006; Görög et al., 2010; Dardon et al., 2010; Briguglio and Benedetti, 2012; Briguglio et al., 2013, 2014; Ferrández-Canadell et al., 2014; Eder et al., 2016).

This technique can be used for instance: to quantify volumetrically cells of foraminifera (Eder et al., 2016); to study the growth and functional morphology by volume measurements and surface of the chambers (Briguglio et al., 2014); to identify small perturbations in the cell growth and deviations in growth by the distance of the septum (Briguglio et al., 2013) and, to execute biometric analysis (Briguglio and Beneditte, 2012).

There are several types of tomographs, which can be supplied by different companies. Some types of tomographs are more suitable for large materials and allow to scan ossicles, teeth, minerals, small pieces of fossil plants, porosities and microstructures of different natures (Lasso et al., 2008; Garwood et al., 2009; Garwood and Sutton, 2010). Micro-CT is able to scan at high resolution, materials with micrometers dimension, including foraminifera (Görög et al, 2010; Briguglio and Benedetti, 2012; Briguglio et al., 2013, 2014; Ferrández-Canadell et al., 2014; Eder et al., 2016), or nanometers dimension.

For building a 3D-model, specific software is needed. The images of the sliced materials can be joined to form a 3D object through the software such as Mimics, 3D-Doctor (Dardon et al., 2010), as well as the Avizo and InVesalius, which display an algorithm named "shape from silhouettes" (Zhou and Tönnes, 2004; Velaz et al., 2008; Solimene et al., 2010; Tan and Jiang, 2011). This algorithm is similar to a photogrammetry software and its approach is called Visual Hull, a geometric entity defined by the shape of silhouette of the object in 3D-technique (Laurentini, 1994).

Görög et al. (2010) suggested that the 3D-technique is very effective in fossils of small dimension since it provides high richness of detail.

Computed Micro-CT has the same technical basis of the computed tomography, but is an improvement of X-rays inspection techniques and is non-invasive and also displays micrometer resolution (Lima et al., 2007; Dardon et al., 2010; Görög et al., 2010). 
For its application in Micropaleontology the CT technique requires small adjustments due to the small dimension and differences in the fossils density (Dardon et al., 2010). The algorithm used in microtomography processes the three-dimensional model by varying density captured by CT scans (Dardon et al., 2010; Grillo et al., 2011; Tan and Jiang, 2011).

The Micro-CT applied to micropaleontological materials, namely to foraminifera morphological analysis, is advantageous because it is not destructive (Görög et al., 2010).

\subsection{Foraminifera}

Foraminifera are single-celled organisms. They can have one or many nuclei. Foraminifera also possess granuloreticulose pseudopodia. They are essentially marine protozoa that emerged in the Cambrian, about 570 million years ago, and lived until today (Seyve, 1990; Lin, 1992; Goldstein, 1999; Scott, et al., 2001). These organisms although appeared in the Cambrian period and diversified and invaded all marine environments in the Phanerozoic (Seyve, 1990; Lin, 1992; Goldstein, 1999; Scott, et al., 2001).

They are very abundant and diverse in modern oceans, occurring from the transitional environments, to continental shelves until the abyssal plain and hadal environments (Seyve, 1990; Arenillas, 2004).

Foraminifera can be applied in several research areas, such as, in ecology and paleoecology, for several reasons: occupy all marine environments, from the lower areas to the deepest parts of the ocean; they are abundant and varied in a small amount of sample; they have a hard test that is quite well preserved in the sediment; it is relatively ease to collect and separate them from the sediment; they are sensitive and respond quickly to changes in the environment (Schönfeld et al., 2012). Moreover, they have short reproductive cycles and displayed a rapid evolution in time (Goldstein, 1999; Murray, 2012).

These organisms respond very directly to the changes that occur in their habitat due to their sensitivity to environmental factors, such as salinity, temperature, $\mathrm{pH}$, substrate, organic matter and oxygen content (Martins et al., 2010, 2013, 2014, 2015a, 2015b). So they have been used as environmental bioindicators due to their sensitivity to natural and anthropogenic changes that are reflected in their abundance, species composition of the assemblages and even in the ornamentation of their tests (Frontalini and Coccioni, 2011).
The test is a fundamental structure of foraminifera (Loeblich and Tappan, 1964). Foraminifera build their tests with varied materials, ranging from organic substances through agglutinated foreign matter to secreted calcium carbonate, but reportedly including such exotic materials as silica and iron (Lipps, 1973).

The great variety of foraminifera can be separated into three groups on the basis of test construction: those with membranous tests (allogromiids), those with agglutinated tests (textulariids), and those with deposited calcium carbonate walls, including the fusulinids, miliolids, and rotaliids (Lipps, 1973; Loeblich and Tappan, 1964, 1988).

The test is the element most studied of foraminifera, since the current classification is based almost exclusively on its characteristics (Debenay et al., 1996). The morphology, composition and microstructure serve to distinguish between genera and species (Loeblich and Tappan, 1964). The external morphology of the test can be relatively simple or extremely complex. The most complex tests are formed by a succession of chambers (multilocular) which are separated from each other by partitions called septa (Loeblich and Tappan, 1964). Each chamber communicates with each other by foramina, holes that allow contact between two contiguous chambers (Bignot, 1982). The last chamber communicates with the exterior through one or several apertures. Consequently, the general aspects of multilocular tests are extremely diverse (Loeblich and Tappan, 1964, 1987).

\section{Materials and Methods}

This study applied the Micro computed tomography (Micro-CT) to a specimen of foraminifera, Pyrgo depressa (d'Orbigny, 1826) (Fig. 1) from Pleistocene strata, of core PC7-1, collected in the NW Iberian Margin (42.40'29'N, $\left.11^{\circ} 09^{\prime} 48^{\prime \prime} \mathrm{W}, 1.675 \mathrm{~m}\right)$. The genus Pyrgo belongs to: Order Miliolida, Suborder Miliolina, Superfamily Milioloidea, Family Hauerinidae, Subfamily Miliolinellinae (according to World Register of Marine Species, accessed on 04.05.2016). This is considered an epifaunal and a typically bathyal taxon (Alavi, 1988; Murray, 1991).

The external morphology of the analyzed specimen of $P$. depressa was photographed with Zeiss Stereo Discovery V12 microscope. This specimen was then analyzed with a microCT. In this work, a Sky Scan 1172 Microtomograph was used, which provides a resolution of up to 0.4 micrometers detection, and the CTVox, 3D-Doctor, 3Dsom software, which have the algorithm "shape from silhouettes" as well as the Ctan and DataViewer software, for analysis of Micro- 
CT scans. The 3D-Max and Maya software were also used for modeling, treatment of three-dimensional models and animation.

The tomographic images of the studied specimen were analyzed with the 3D-Doctor software, which allowed the observation of each image and generate a 3D-model. They were also analyzed by the CT-microtopographies in DataViewer software for observation in the three axes $(\mathrm{X}, \mathrm{Y}$ and Z). The CTVox software was also used for creating a virtual video to analyze specimens. The Ctan software was used to analyze differences in the test density.

All procedures of analysis and the 3D-model generation were performed in Micropaleontology Laboratory, of the Faculty of Geology, at the Universidade do Estado Rio de Janeiro. For computed microtomography was used the SkyScan 1172 Microtomograph of the Embrapa Laboratory (Embrapa Agricultural Instrumentation), São Carlos, Brazil.

\section{Results}

The analyzed specimen of $P$. depressa was photographed with a light microscope (Fig. 1). These photos provide a general view of the test. The tomographic images are presented in Figures 2-9.

Figure 2 shows external features of the test and internal arrangement of the chambers of the analyzed specimen at the resolution of 2D-model (tomographic images) and 3Dmodel (by 3D-Doctor and DataViewer software, respectively).

Figure 3 presents a 3D-model view performed by the CTVox software in several positions including both internal and external views. In Figure 4 is also presented a 3D-model view of $P$. depressa performed by the Ctan software, which evidences different densities of the test. The highest densities are observed in the most calcified parts of the test.

In the Figure 5, 2D-models and 3D-models of several test sections can be compared. The image $\mathrm{B}$ of this figure also shows the variation of the density of materials of the studied specimen. The images included in this figure evidence the occurrence of sediment deposited inside the test.

The 3D-models performed and treated by 3D-Max and Maya software are presented in Figure 6. These models evidence the thickness of the chambers' walls and the initial chamber of the $P$. depressa test (proloculus).

Details of the apical region of the test of the analyzed specimen can be observed in Figure 7, in two 3D-models obtained from 3D-Max and CTVox software. This figure highlights particularities of the specimen's aperture showing a plate. This image obtained though the CTVox, also shows the initial internal chambers arrangement.

The CT-scan analyzed with the 3D-Max and Maya software enabled to examine sections of the 3D-model of the analyzed $P$. depressa specimen (Fig. 5). It was possible to observe details with a sharply definition of its internal structure, including the internal side of the walls, foramina, depressions and inner chambers cross sectional arrangement. A detail of the sediment deposited within its chambers is also observed.

The use of the Ctan software facilitated the observation of differences in densities and structures found in the other images obtained in the scans using the DataViewer and CTVox software (Fig. 6).

The apical view of $P$. depressa and aperture, in two 3Dmodels performed by 3D-Max and CTVox software, is shown in Fig. 7 ( $\mathrm{A}$ and $\mathrm{B}$, respectively). These models evidence the external biconvex structure of the test, the marginal keel, encircling the test at its equatorial line and the smooth wall (with soft roughness). The wall is not perforated. The marginal keel remains in the oral region, flanking one side of the aperture and giving rise to dental apparatus constituted by two prominent teeth.

Figure 8 presents a 3D-model image obtained by CTVOx software. This image shows the proloculus and evidences the intercameral thickened septa that delimit two successive chambers.

Additionally, the 3D-models images obtained by CTVOx software presented in Figure 9 display the central structure of $P$. depressa: the external and internal structure of the proloculus, as well as its aperture.

The 3D-moddle of the analyzed $P$. depress $a$ is included in the supplementary material 1 (SM1), performed with the CTVox software. This software can produce a video to visualize the inside and outside morphology.

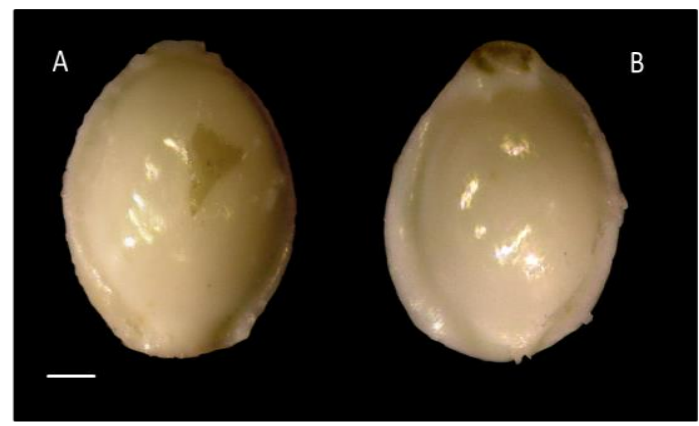

Fig. 1. The species Pyrgo depressa observed in two sides of the test (A and B; scale of $100 \mu \mathrm{m}$ ). The aperture is observed in the apical extremity of the test. 

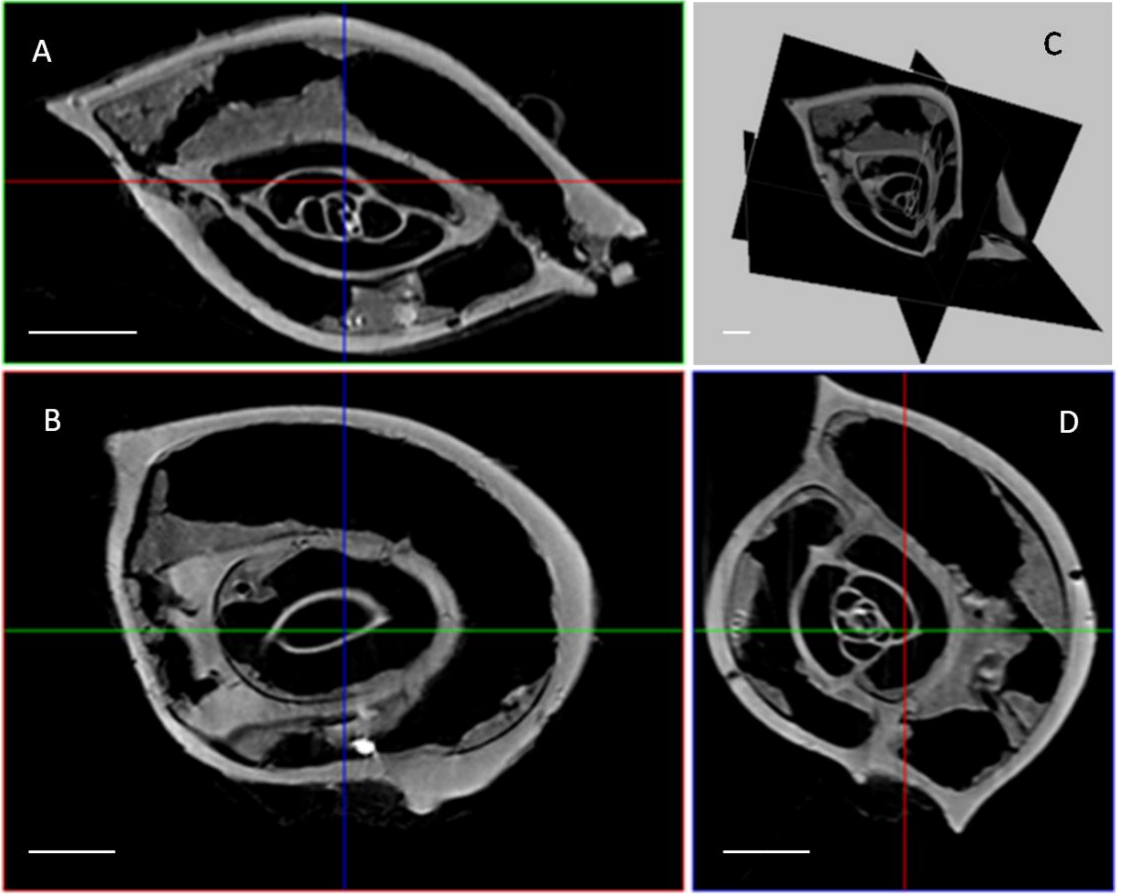

Fig. 2. Photos A, B, C and D resulted from scans analyzed using the Dataviewer software. Photos: A. longitudinal section from aboral to apical extremities; B. longitudinal section from aboral to apical extremities at perpendicular to A. C - three axis view. D. transversal section. Scale $100 \mu \mathrm{m}$.

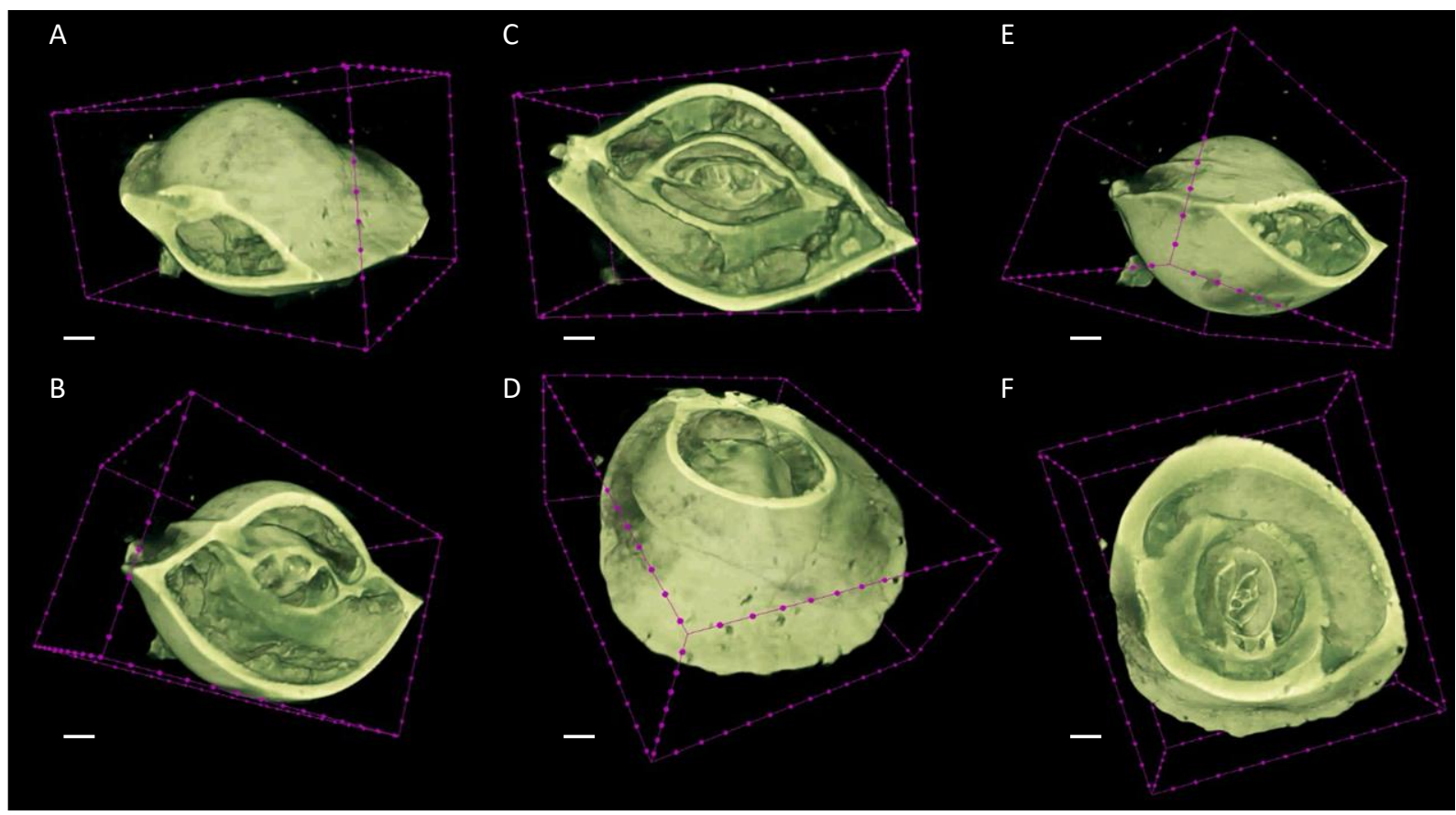

Fig. 3. The 3D-model view performed by the CTVox software in several positions including both internal and external views. Scale $50 \mu \mathrm{m}$. 


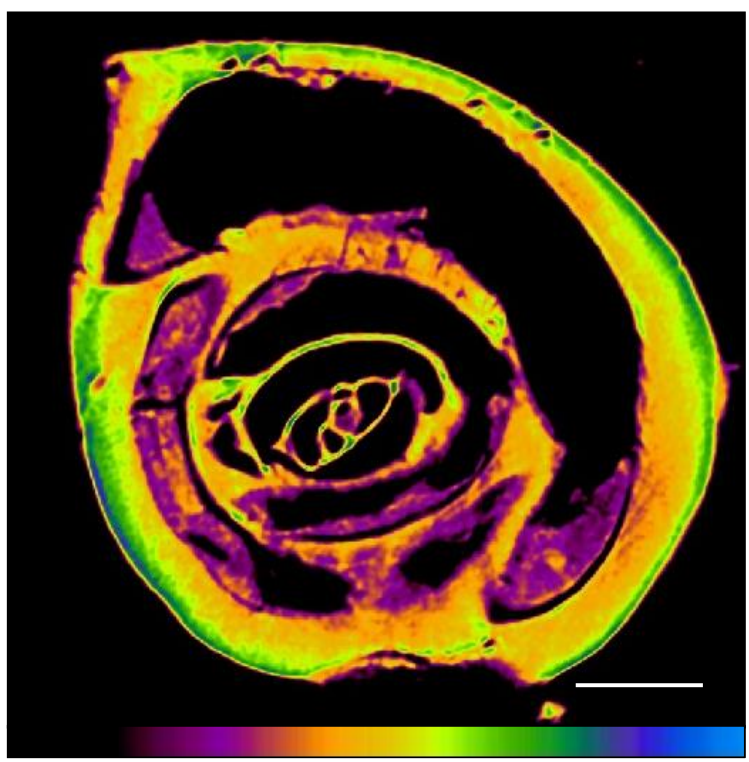

Fig. 4. A 3D-model view of $P$. depressa performed by the Ctan software (scale $50 \mu \mathrm{m}$ ). The image evidences density differences. The semiquantitative scale is displayed (below the photo). Color scale: the black color represents empty spaces; the lowest density is represented by pink and the blue is used to mark the highest densities parts of the test.

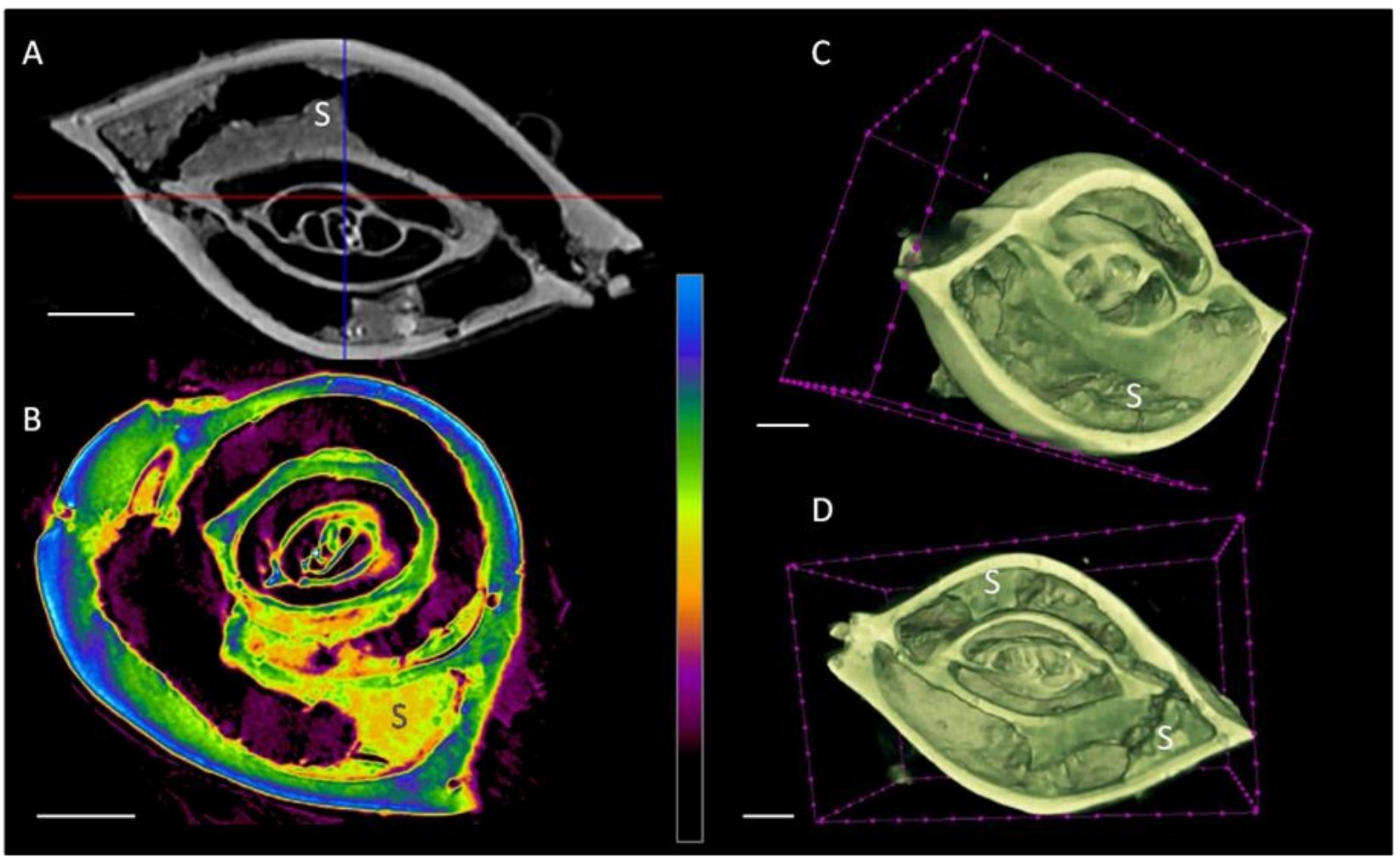

Fig. 5. A. Apical-aboral longitudinal section view obtained with the Dataviewer software. B. image obtained by the Ctan software, showing density differences in median cut of test between the keel. C. 3D-model of section B. D. 3D-model of the section. Images C and D were obtained by the CTVox software. A. Legend. S - sediment deposited inside the test. Sediments are evidenced by the letter S. Scale $50 \mu \mathrm{m}$. Color scale: the black color represents empty spaces; the lowest density is represented by pink and the blue is used to mark the highest densities parts of the test. 


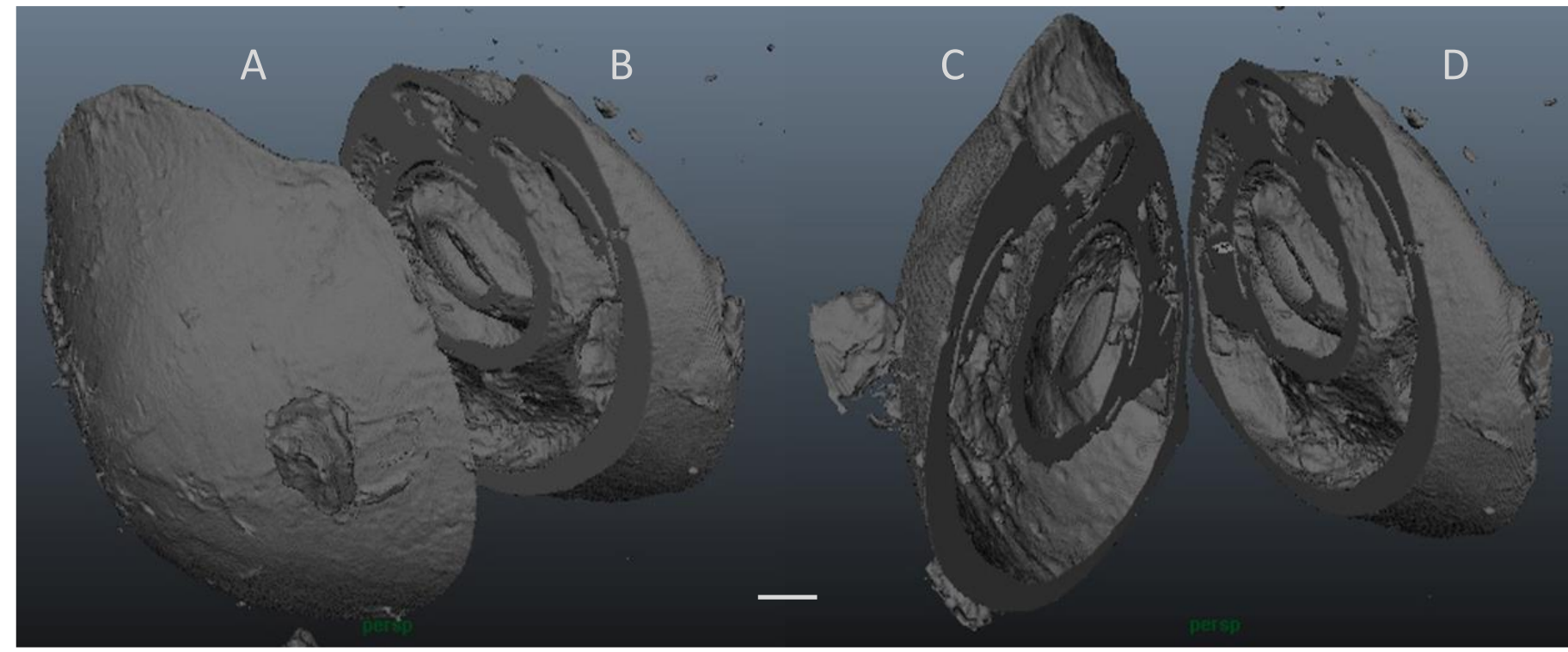

Fig. 6. Sections of Pyrgo depressa allowing the visualization of its interior. These 3D-models were performed and tread by 3D-Max and Maya software. Scale $50 \mu \mathrm{m}$.

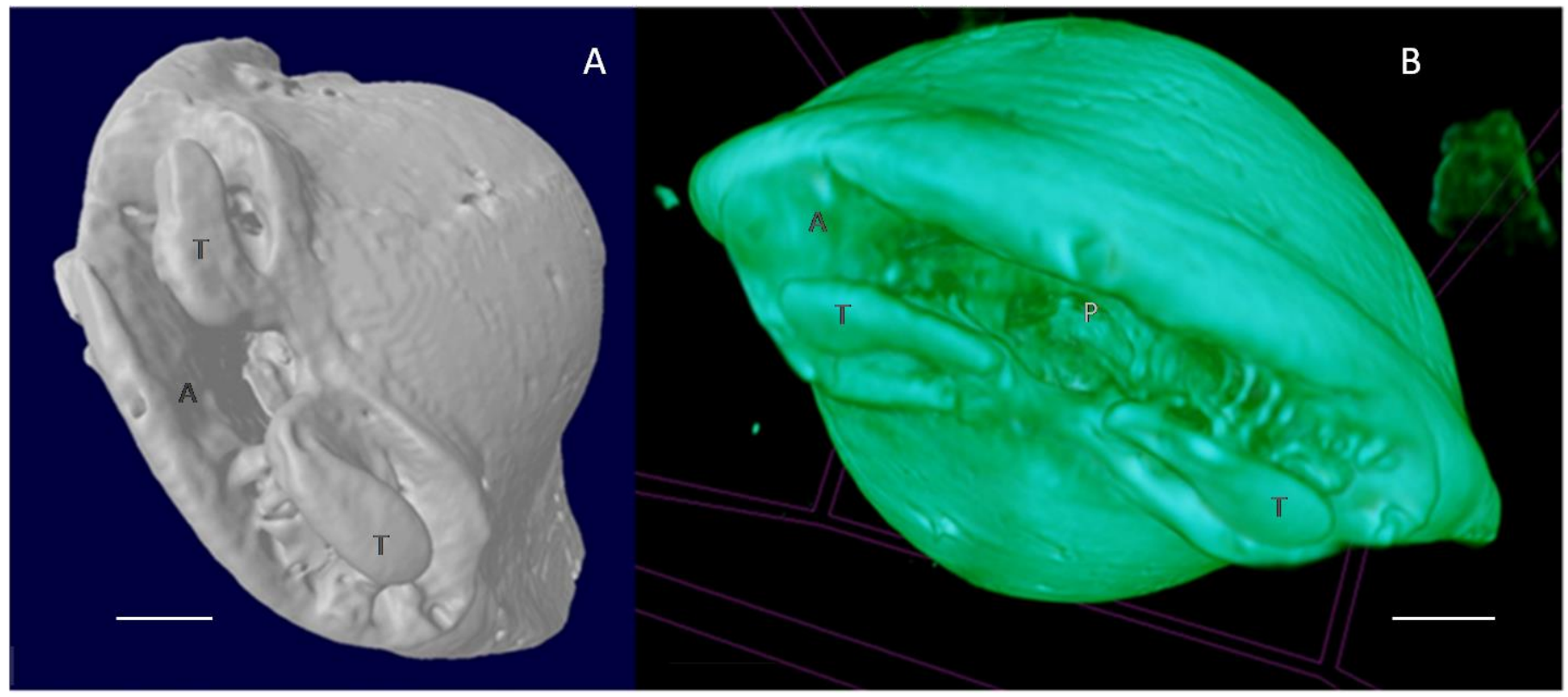

Fig. 7. The apical view of P. depressa apertura, in 3D-models by: A. 3D-Max software; B. CTVox software. Scale of $50 \mu \mathrm{m}$. Legend: P proloculo. T - Tooth. A. aperture. 


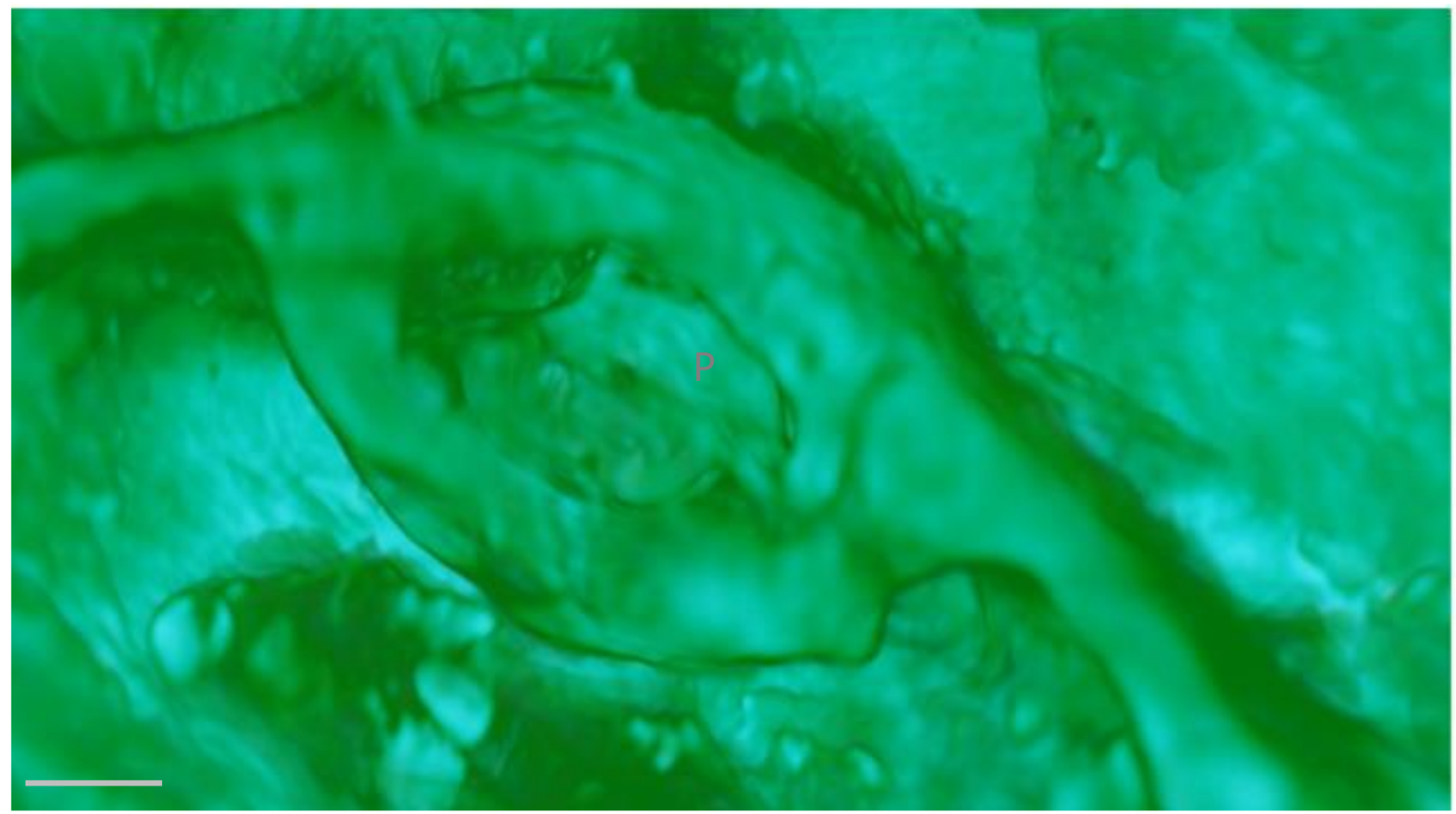

Fig. 8. A 3D-model image obtained by CTVox software, of P. depressa showing the proloculus $(\mathrm{P})$ and the initial internal chambers arrangement. Scale $10 \mu \mathrm{m}$.

\section{Discussion}

The physical principle of the micro-CT (computed microtomography) and $\mathrm{CT}$ are based on the attenuation of $\mathrm{X}$-rays when they interact with the object. The intensity of the photons passing through the object depends on the number of atoms per unit volume (density) and type of atoms along the beam (Laurentini, 1994). Essentially, the quality of micro-CT image depends on spatial resolution, contrast signal and noise. However, one of the most important parameters in micro-CT is the size of the pixel scanning, which is linked with the spatial resolution of the system (Laurentini, 1994).

In this work, the 3D-models resulted from set of coordinates included in a spatial network, which is formed by the shape from silhouettes of the scanned material captured by the images generated by the SkyScan 1172 microtomograph or micro-CT. This has an algorithm that generates a spatial mesh, the object silhouette through the photographs (Kim et al., 2010).

One of the most popular methods for this purpose is the use of the algorithm, which calculates the 3D-shape from solid materials by volume intersection by silhouette (Solimene et al., 2010; Grillo et al., 2011). Every point captured by the silhouette through a $2 \mathrm{D}$-image of the object is segmented through the formation of the space cone (Solimene et al., 2010; Grillo et al., 2011).

The intersection of high number of cones captured by the micro-CT at different positions of the detector enables to estimate the 3D-model volume of the analyzed object. This algorithm is called Visual Hull, a geometric entity defined by the shape of silhouette of the object in 3D-technique (Laurentini, 1994; Solimene et al., 2010).

The 1808 tomographic images and the 3D-model of the studied specimen analyzed with the 3D-Doctor, CTVox, DataViewer, 3D-Max, Ctan and Maya software, allowed to evidence different kind of internal and external structures.

The 3D-Doctor software analyzes a plan of the microCT (Fig. 2). This program makes the integration of all monoplane tomographic images and can generate a 3Dmodel (Fig. 2 E, F).

On the basis of the DataViewer software, it is possible to analyze simultaneously three axes plane (Fig. 2 A-D). Figure 2 (A, B, D) presents three axes of the test sections, which are integrated in Fig. 2C. These pictures display the wall thickness of the chambers, the number of chambers around the coiling axis, the inner filling of the chambers, the intercameral septa, apertures, among other features. 

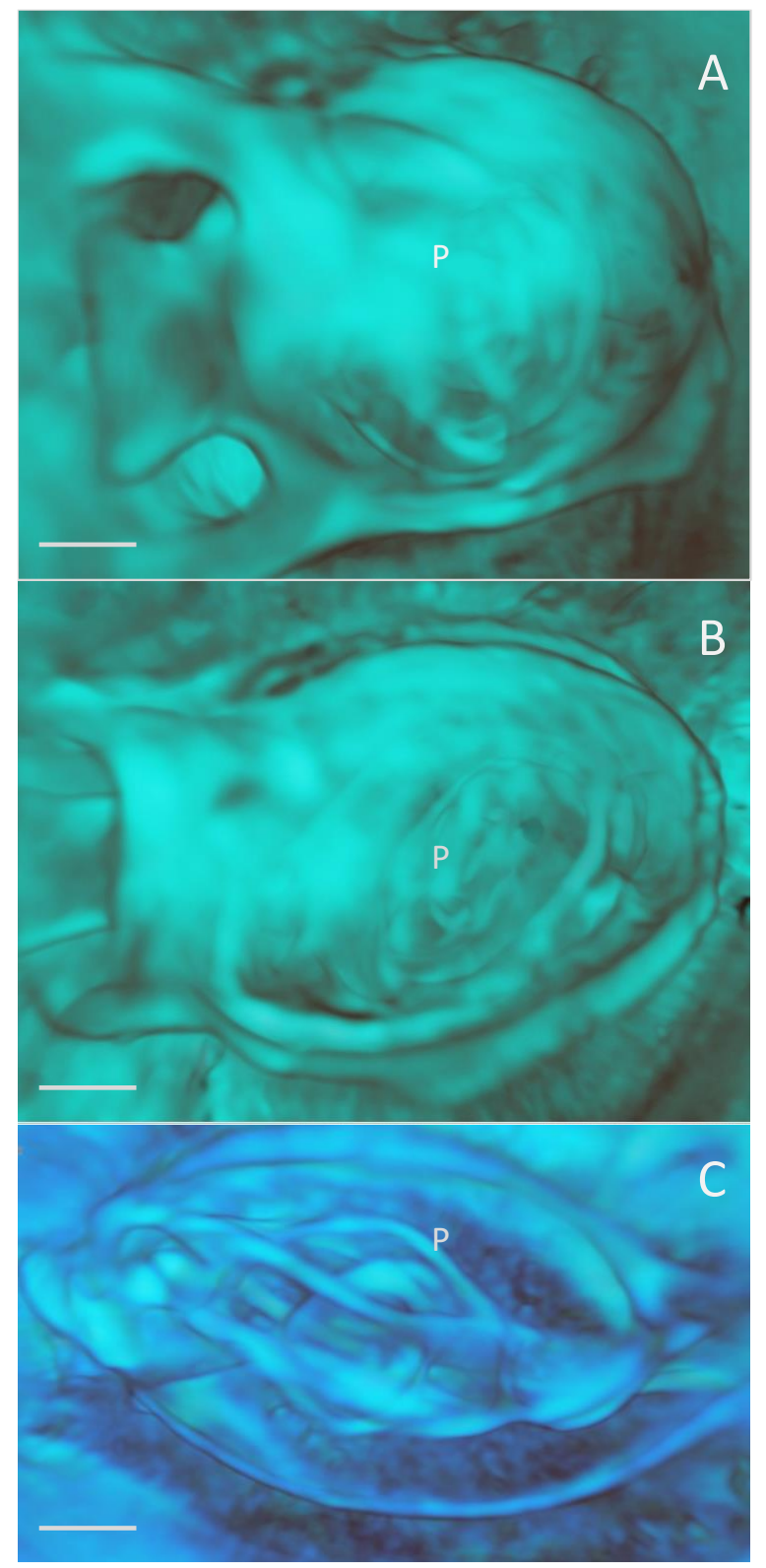

Fig. 9. 3D-model images obtained by CTVox software, of $P$. depressa showing the central structure of the specimen evidencing the proloculus $(\mathrm{P})$ : A. External wall of the proloculus; aperture detail with lateral expansions. B. the channel of one of the apertures. C. internal structure of the wall of proloculus with multiple columnar thickenings. Scale $3 \mu \mathrm{m}$.

The 3D-model obtained by the CTVox software, is composed by the micro-CT photos, allowing the differentiation of structures using a color spectrum (Figures $3,5 \mathrm{C}, \mathrm{D}, 7 \mathrm{~B}, 8,9)$. This software cuts the 3D-model, at various depths (Fig. 3, Fig. 5C, D), and has the function to make more translucent, allowing a better analysis of internal structures (Figs. 9).

By the Ctan software, we are able to evidence density differences (Fig. 4, 5B). This program allows us to note that as the test grows, the external chambers are becoming progressively thicker and denser, or more calcified. The test region with denser wall corresponds to the keel both at the initial chambers as at the final one. This program also evidences material deposited on and inside the chambers. In the studied specimen, the deposited material displays in general low density, which should correspond to remains of organic matter (density of $0.472 \mathrm{~g} / \mathrm{cm}^{3}$; according to Olukayode et al., 2012). However, in some areas, it is possible to observe, relatively dense material, but less than that which constitutes the test. As the density of the calcite is about $2.711 \mathrm{~g} / \mathrm{cm}^{3}$ (Calcite mineral information and data. - Mindat.org, http://www.mindat.org/min-859.html, accessed on 04.05 .2016 ) and quartz is $2.65-2.66 \mathrm{~g} / \mathrm{cm}^{3}$ (Quartz mineral information and data, in http://www.mindat.org/min-3337.html, accessed on 04.05.2016) we can deduce that terrigenous sediments are deposited in some parts of the test of the analysed specimen.

The 3D-Max and Maya software are very useful for the treatment of three dimensional models. They can handle 3D objects facilitating the visualization of their structures, as shown in Figures 6 and 7A. The Figure 6 evidences the wall thickness of the inner and outer chambers, the space within the chambers and wall roughness. It was obtained simultaneously by 3D-Max, which allowed a good rotation of the specimen, and Maya software, which allowed to improve image quality by removing the noise.

\subsection{Special features observed in P. depressa based on the Micro- CT}

The test of $P$. depressa specimen observed in this work, with a diameter of about $0.4 \mathrm{~mm}$, has a circular outer contour, an acute peripheral edge and a large and thickened keel. The wall is carbonated (porcelaneous) smooth and imperforate (Figs. 1, 3, 7).

The test, composed by 13 chambers, including a proloculus (Fig. 2D), is ovate in outline view, compressed through the midpoint of the opposing chambers (Figs. 1, 3, 7). The midpoint between two chambers has a developed keel periphery.

The early chambers display a quinqueloculinoid arrangement composed by 2 whorls of the coil (Fig. 2D), which is followed by a biloculinoid arrangement (Figs. 2, 5). 
The chambers of the biloculinoid disposal, occupy one half coil in length. The aperture at the end of the final chamber is a slit flanked by two curved teeth (Fig. 7). These morphological characteristics agree with the description of Loeblich and Tappan (1988) for the genus Pyrgo.

However, the 3D-Models allowed to evidence some structures never before described. The proloculus has two apertures, positioned at opposite ends (Fig. 9A, B; SM1). The following chambers have one aperture with the same configuration. These apertures are not always aligned with that of the last chamber. However, the main aperture of the proloculus, which is clearly well defined (see Fig. 9 A, B) is aligned with the final apertural slit (Fig. 7).

The final aperture is an extensive and relatively wide slit that connect directly with internal chambers (Fig. 7). The aperture at the apical end of the last chamber has a configuration/structure identical to the previous chambers but larger in size, since the most internal chambers are smaller (SM 1).

The dental slab of the proloculus is merged with the wall of the next chamber, creating its initial part of the keel (Fig. 9A). This relationship of the toothplates is observed in all the chambers (SM1). That is, the dental slab of the anterior chamber supports the beginning formation of the wall of the next chamber, being associated with its keel. The role of the toothplate should be to give support to the next chamber formation.

The proloculus wall seems to be complex (Fig. 9C; SM1). It is composed by internal multiple columnar thickenings. Every two columns support a part of the outer wall of the proloculus. These columnar thickenings are associated with the septa of the primary chambers that constitute the quinqueloculine coiling.

As the test grows, the outer chamber walls are becoming denser and thick (Figs 3, 4, 5, 6). The highest densities are observed in the last chambers, particularly in the keel that compose the outer edge. Through the density spectrum analysis, it is possible to perceive the presence of organic matter and sediment within the test.

\section{Conclusion}

The use of 3D-Doctor software allowed the generation of 3D-models of the external and internal structure of the foraminifera test. The high resolution of 1172 SkyScan Micro-CT allowed a denser internal three-dimensional mesh, which resulted in a clear definition of the chambers in the 3D-models. These models show particularities that are not possible to easily observed and perceived with the microscopic methods traditionally used in the morphological analysis of microorganisms.

Moreover, the specific software used in this work display functions, which can be used to produce a video of the threedimensional structure of the studied materials. The movie allows the observation and further analyzes of the configuration and position of internal structures. These techniques of analyses may allow a more accurate description of the characteristics of the species.

In this case, it allows better account for the number, size and spatial arrangement of chambers, as well as other internal details, such as the wall, aperture and proloculus configuration, shape and number of foramina.

\section{Acknowledgements}

The authors would like to thank the Embrapa Instrumentação Agropecuária de São Carlos-SP for the generation of computerized tomography of the analyzed specimen of $P$. depressa and also to thank Ricardo G. Mendes for the operation of the equipment of the SkyScan 1172 Micro-CT. We thank the laboratory macrofossils of the Department of Geology and CCMN-UFRJ, by using 3DDoctor software, facilitating the analysis of CT scans and enable the generation of the 3D-models of the analyzed specimen of $P$. depressa and also the Virtual Institute of Paleontology of the State of Rio de Janeiro (RJ-IVP) by hosting the supplementary material. We emphasize that without the partnership of such laboratories this work would not be possible.

\section{Supplementary material 1}

http://www.ivprj.uerj.br/crbst_57.html

\section{References}

Alavi, S.N., 1988. Late Holocene deep-sea benthic foraminifera from Sea of Marmara. Marine Micropaleontology 13, 213-237.

Arenillas, I., 2004. Bioestratigrafía, limitaciones y ventajas de los microfósiles. In, Molina, E. (ed.). 2004. Micropaleontología. Zaragoza, Prensas Universitárias de Zaragoza, 571-590 pp.

Azevedo, S.A.K., Carvalho, L.B., Santos, D.D., 2010. Metodologias digitais aplicadas no estudo de vertebrados. In: Carvalho, I.S., Paleontologia, $3^{\mathrm{a}}$ ed., Rio de Janeiro, Editora Interciências, 1, 445-450.

Azevedo, S.A.K., Carvalho, L.B., 2009. O uso da tomografia computadorizada no estudo de vertebrados fósseis. In: $\mathrm{H}$. Werner Jr., J. Lopes (Org.), Tecnologia 3D Technologies, Paleontologia, Arqueologia e Fetologia. Rio de Janeiro, Livraria e Editora Revinter, 1-32 pp.

Baumgartner-Mora, C., Baumgartner, P.O., Baumgartner, L., 2006. 3D-imaging of foraminifera by X-ray microtomography. Anuário do Instituto de Geociências - UFRJ, 29 (1), 323-324. 
Bignot, G., 1982. Les Microfossiles. Les diffèrents groupes. Exploitation paléobiologique et géologique. Dunod, Bordas, Paris, 212 p.

Birkmann, H., Lundin, R.F., 1996. Confocal microscopy, potential applications in micropaleontology. Journal of Palaeontology 70, 10841087.

Briguglio, A., Wöger, J., Wolfgring, E., Hohenegger, J., 2014. Changing Investigation Perspectives: Methods and Applications of Computed Tomography on Larger Benthic Foraminifera. Chapter 4. In: H. Kitazato and J.M. Bernhard (eds.) Approaches to Study Living Foraminifera: Collection, Maintenance and Experimentation, Environmental Science and Engineering, Springer Japan. p 55-70. doi: 10.1007/978-4-431-54388-6_4

Briguglio, A., Hohenegger, J., Less, G., 2013. Paleobiological applications of three-dimensional biometry on larger benthic foraminifera: A new route of discoveries. Journal of Foraminiferal Research 43, 72-87. doi:10.2113/gsjfr.43.1.72.

Briguglio, A., Benedetti, A., 2012. X-ray microtomography as a tool to present and discuss new taxa: The example of Risananeiza sp. from the late Chattian of Porto Badisco. Rendiconti Online Societa Geologica Italiana 21 (Part 2), 1072-1074 pp..

Brochu, C.A., 2000. A digitally-rendered end cast for Tyrannosaurus rex. Journal of Vertebrate Paleontology 20 (1), 1-6.

Dardon, U., Souza, R.S., Abranches, C.T.S., Bergqvist, L.P. 2010. Modelagem 3D e suas aplicações na pesquisa paleontológica. Gaea 6 (2),76-89.

Debenay, J.-P., Pawlowski, J, Decrouez, D., 1996. Les foraminifères actuels. MASSON, Paris, 329 p.

Duarte, L.C., Juchem, P.L., Pulz, G.M., Brum, T.M.M., Chodur, N., Liccardo, A., Fischer, A.C., Acuan, R.B., 2003. Aplicações de microscopia eletrônica de varredura (MEV) e sistema de energia dispersiva (EDS) no estudo de gemas, exemplos brasileiros. Pesquisas em Geociências 30(2), 3-15.

Eder, W., Briguglio, A., Hohenegger, J., 2016. Growth of Heterostegina depressa under natural and laboratory conditions. Marine Micropaleontology 122, 27-43.

Ferrández-Cañadell, C., Briguglio, A., Hohenegger, J., Wooer, J., 2014. Test fusion in adult foraminifera: A review with new observations of an early Eocene Nummulites specimen. Journal of Foraminiferal Research 44 (3), 316-324. doi: 10.2113/gsjfr.44.3.316

Frontalini, F., Coccioni, R., 2011. Benthic foraminifera as bioindicators of pollution, a review of Italian research over the last three decades. Revue de Micropaleontologie 54, 115-127.

Garwood, R., Dunlop, J.A., Sutton, M.A., 2009. High-fidelity Xray microtomography reconstruction of siderite- hosted Carboniferous arachnids. Biology Letters 5, 841-844.

Garwood, R., Sutton, M., 2010. X-ray micro-tomography of carboniferous stem-dictyoptera, new insights into early insects. Biological Letters 6, 699-702.

Goldstein, S.T., 1999. Foraminifera, a biological overview. In: Sen Gupta, B. K. (Ed.), Modern Foraminifera. Kluwer Academic Publishers, London, 37-55 pp.
Görög, Á., Szinger, B., Tóth, E., Viszkok, J., 2010. Methodology of the micro-computer tomography on foraminifera. Palaeontologia Electronica 15, 3T, 15p.

Grillo, O.N, Romano, P.S.R., Monnerat, M.C., 2011. Comments on the paper modelagem $3 \mathrm{~d}$ e suas aplicações na pesquisa paleontológica (3D-modeling and its application in paleontological research). Gaea 7(1), 77-81.

Hay, W.W., Sandberg, P.A., 1967. The scanning electron microscope, a major break-through for micropaleontology. Micropaleontology 13, 407-418.

Kim, D, Ruttle, J, Dahyot, R., 2010. 3D Shape estimation from silhouettes using mean-shift. IEEE-ICASSP, 1430-1433 pp.

Lasso, P.R.O., Vaz, C.M.P., Naime, J. de M., 2008. Recomendações para utilização do microtomógrafo de raios-x sky scan 1172 em ciências agrárias e biológicas. São Carlos, Embrapa Instrumentação Agropecuária, Documentos 37, 22 p.

Laurentini, A., 1994. The visual hull concept for silhouette-based image understanding. IEEE Transactions on Pattern Analysis and Machine Intelligence 16 (2), 150-162.

Lima, I., Appoloni, C., Oliveira, L., Lopes, R.T., 2007. Caracterização de materiais cerâmicos através da microtomografia computadorizada 3D. Revista Brasileira de Arqueometria, Restauração e Conservação 1(2), 22-27.

Lin, J., 1992. Paleoecology, Paleoclimate and Paleography of Quaternary Foraminiferal Faunas in China. Ph. D. Thesis, Free University of Brussels, $152 \mathrm{p}$.

Lipps, J.R., 1973. Test structure in foraminifera. Annual Review of Microbiology 27, 471-488.

Loeblich, A.R., Tappan, H., 1964. Sarcodina, chiefly thecamoebians and foraminiferida. In: Moore, R.C. (Ed.), Treatise on Invertebrate Paleontology, Geological Society of America, University of Kansas Press, New York, vol. 1, 1- 510 pp., vol. 2, 511- 900 pp.

Loeblich, A.R.Jr., Tappan, H., 1988. Foraminiferal Genera and Their Classification. Van Nostrand Reinhold Company, New York.

Luo, Z. X., Ketten, D.R. 1991. CT scanning and computerized reconstructions of the inner ear structure of multituberculate mammals. Journal of Vertebrate Paleontology 11(1), 220-228.

Maisey, J., 2001. CT-Scan reveals new cranial features in Devonian Chondrichthyan "Cladodus" wildungenesis. Journal of Vertebrate Paleontology 21(4), 807-810.

Mallison, H., Hohloch, A., Pfretzschner, H., 2009. Mechanical digitizing for paleontology - new and improved techniques. Palaeontologia Electronica 12 (2), 1-41.

Martins, V.A., Silva, F., Lazaro, L.M.L., Frontalini, F., Clemente, I.M., Miranda, P., Figueira, R., Sousa, S.H.M., Dias, J.M.A., 2015a. Response of benthic foraminifera to organic matter quantity and quality and bioavailable concentrations of metals in Aveiro Lagoon (Portugal). PLoS One 10 (2), e0118077. doi.org/10.1371/journal.pone. 0118077. 
Martins, M.V.A., Zaaboub, N., Aleya, L., Frontalini, F., Pereira, E., Miranda, P., Mane, M., Rocha, F., Laut, L., El Bour, M., 2015b. Environmental quality assessment of Bizerte Lagoo (Tunisia) using living foraminifera assemblages and a multiproxy approach PLoS One doi.org/10.1371/journal.pone.0137250

Martins, M.V.A., Frontalini, F., Laut, L.L.M., Silva, F. S., Moreno, J., Sousa, S., Zaaboub, N., El Bour, M., Rocha, F., 2014. Foraminiferal biotopes and their distribution control in Ria de Aveiro (Portugal), a multiproxy approach. Environmental Monitoring and Assessment 186, 12, 8875-8897. Doi: 10.1007/s10661-014-4052-7

Martins, V.A., Frontalini, F., Tramonte, K.M., Figueira, R.C.L., Miranda, P., Sequeira, C., Fernández-Fernández, S., Dias, J.A., Yamashita, C., Laut, L.M., Sobrinho, F., Rodrigues, M.A., Bernardes, C., Nagai, R., Sousa, S.S.M., Mahiques, M., Rubio, B., Bernabeu, A., Rey, D., Rocha, F. 2013. Assessment of the health quality of Ria de Aveiro (Portugal), heavy metals and benthic foraminifera. Marine Pollution Bulletin 70, 18-33.

Martins, V., Ferreira da Silva, E., Sequeira, C., Rocha, F., Duarte, A.C., 2010. Evaluation of the ecological effects of heavy metals on the assemblages of benthic foraminifera of the canals of Aveiro (Portugal). Estuarine, Coastal and Shelf Science 87, 293304.

Murray, J. W., 2012. Unravelling the life cycle of Polystomella crispa, the roles of Lister, Jepps and Myers. Journal of Micropalaeontology 31, 121-129.

Murray, J.W., 1991. Ecology and Palaeoecology of Benthic Foraminifera. London, Longman Scientific \& Technical, 397 pp.

Olukayode, D., Akinyemi, O.D., Aderemi, A., Alabi, A.A., Ojo, A.I., Adewusi, O.E., 2012. Characterization of Density and Porosity of Rocks Samples from Ogun State of Nigeria. Earth Science Research 1, 98-105.
Rowe, T., Brochu, C.A., Kishi, K., 1999. Cranial morphology of Alligator mississippiensis and phylogeny of Alligathoroidea. Journal of Vertebrate Paleontology, 19 (2, Supplement), 100.

Schmidt, R.A.M., 1952. Microradiography of microfossils with Xray diffraction equipment. Science 115, 94-95.

Schönfeld, J., Alve, E., Geslin, E., Jorissen, F., Korsun, S., Spezzaferri, S., Abramovich, S., Almogi-Labin, A., Armynot du Chatelet, E., Barras, C., Bergamin, L., Bicchi, E., Borja, A., Bouchet, V., Cearreta, A., Di Bella, L., Dijkstra, N., Trevisan Disaro, S., Ferraro, L., Frontalini, F., Gennari, G., Golikova, E., Haynert, K., Hess, S., Husum, K., Martins, V., McGann, M., Oron, S., Romano, E., Mello Sousa, S., Tsujimoto, A., 2012. The FOBIMO (FOraminiferal BIo-MOnitoring) initiative - Towards a standardised protocol for soft-bottom benthic foraminiferal monitoring studies. Marine Micropaleontology 94-95, 1-13.

Scott, D.B, Schafer, C.T., Medioli, F.S., 2001. Monitoring in coastal environments using foraminifera and thecamoebian indicators. Cambridge University Press, 192 pp.

Seyve, C., 1990. Introdução à micropaleontologia. Angola, Elf Aquitaine Angola, 231 pp.

Solimene, R., Brancaccio, A., Di Napoli, R., Pierri, R., 2010. 3D sliced tomographic inverse scattering experimental results. Progress in Electromagnetics Research 105, 1-13.

Tan, Y., Jiang, H., 2011. A fluorescence molecular tomography invivo imaging system for macro/meso-scale subjects. Biosensors and Bioelectronics S4, 001. Doi: 10.4172/2155-6210.S4-001.

Velaz, Y., Unzueta, L., Suescun, Á., 2008. Fast human 3d voxelized shape reconstruction for human-computer interaction. International Journal of Computers 4 (2), 371-380.

Zhou, J., Tonnies, K.D., 2004. Sate of the art for volume renderins, technical report. TR-ISGBV-03-02, Institute for Simulation and Graphics, University of Magdeburg. 